2. To: (Receiving Organization)

Distribution

5. Proj./Prog./Dept./Div.:

241-AN CAM Upgrade

8. Originator Remarks:

Acceptance Test Procedure, TWR-4713, to be completed prior to performing the functional test of the AMS-4 CAM.

\section{Receiver Remarks: 11A. Design Baseline Document? $\bigcirc$ Yes $\bigcirc$ No} USQ TF-98-1012/REV.8 FORTHIS ATP CONCLUDES THAT CHANGING TO AMS-4 CAM (S) COMPLIES WITH LCO 3.1.4 AND THAT THE SHSTEM MEETS AB REQUIREMENTS

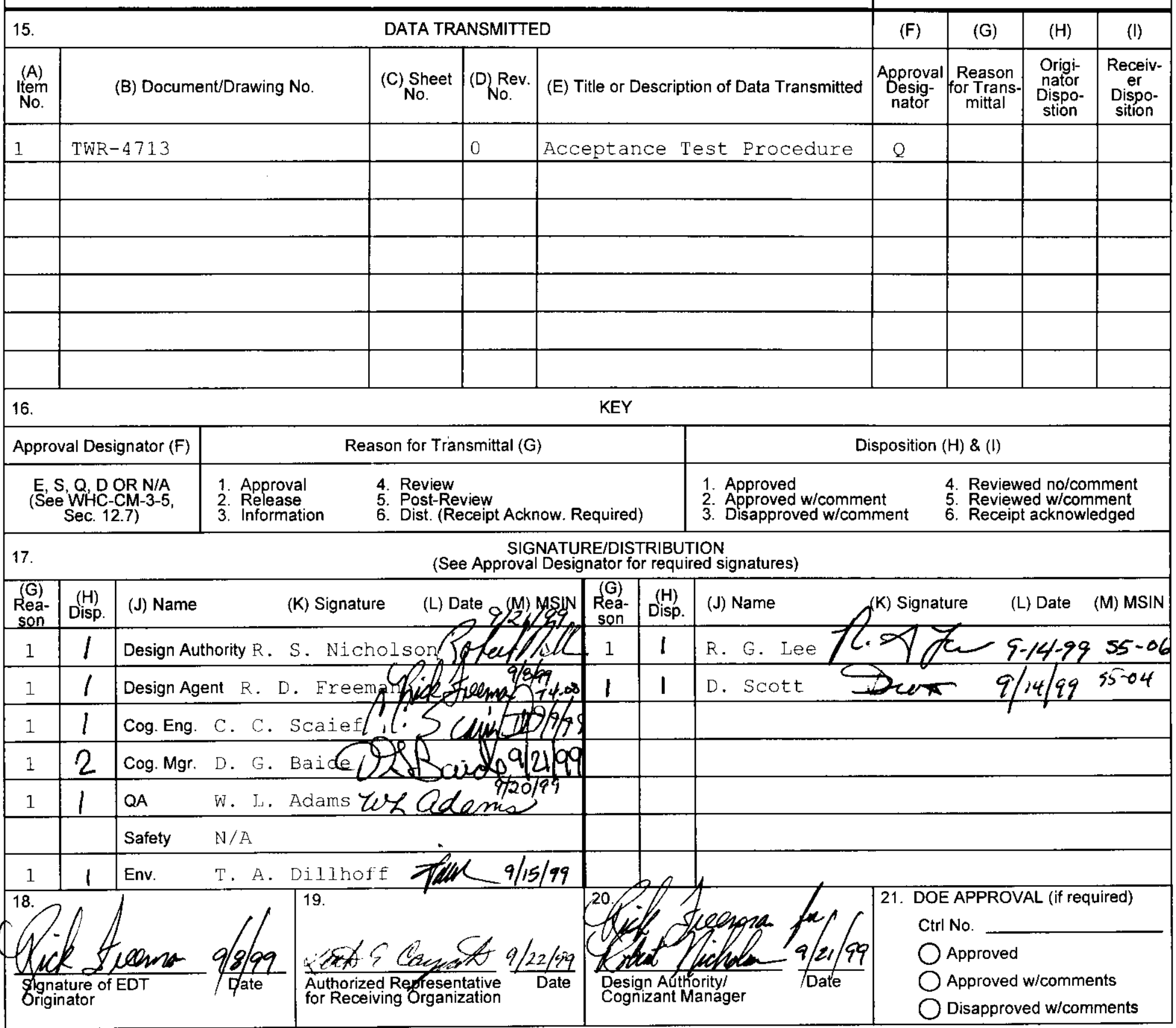

\section{Related EDT No.: \\ $\mathrm{N} / \mathrm{A}$ \\ 7. Purchase Order No.: \\ 9. Equip./Component No.:}

10. System/Bldg./Facility:

12. Major Assm. Dwg. No.:

13. Permit/Permit Application No.:

14. Required Response Date: 
S

\title{
ACCEPTANCE TEST PROCEDURE FOR AMS-4 CONTINUOUS AIR MONITORS AT 241-AN EXHAUSTERS
}

\author{
R. D. Freeman \\ Lockheed Martin Hanford Co. \\ Richland, WA 99352 \\ U.S. Department of Energy Contract DE-AC06-96RL13200

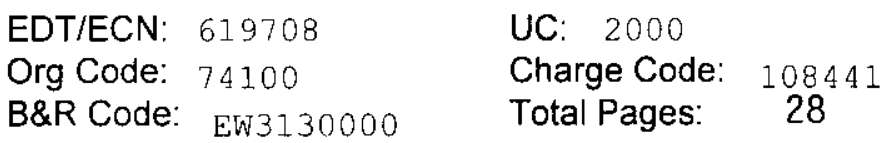

Key Words: Continuous Air Monitor

\begin{abstract}
This supporting document provides detailed instruction for ensuring the existing alarms and interlocks are in an acceptable condition prior to performing the functional test of the AMS-4 installation.
\end{abstract}

TRADEMARK DISCLAIMER. Reference herein to any specific commercial product, process, or service by trade name, trademark, manufacturer, or otherwise, does not necessarily constitute or imply its endorsement, recommendation, or favoring by the United States Government or any agency thereof or its contractors or subcontractors.

Printed in the United States of America. To obtain copies of this document, contact: Document Control Services, P.O. Box 950, Mailstop H6-08, Richland WA 99352, Phone (509) 372-2420; Fax (509) 376-4989.
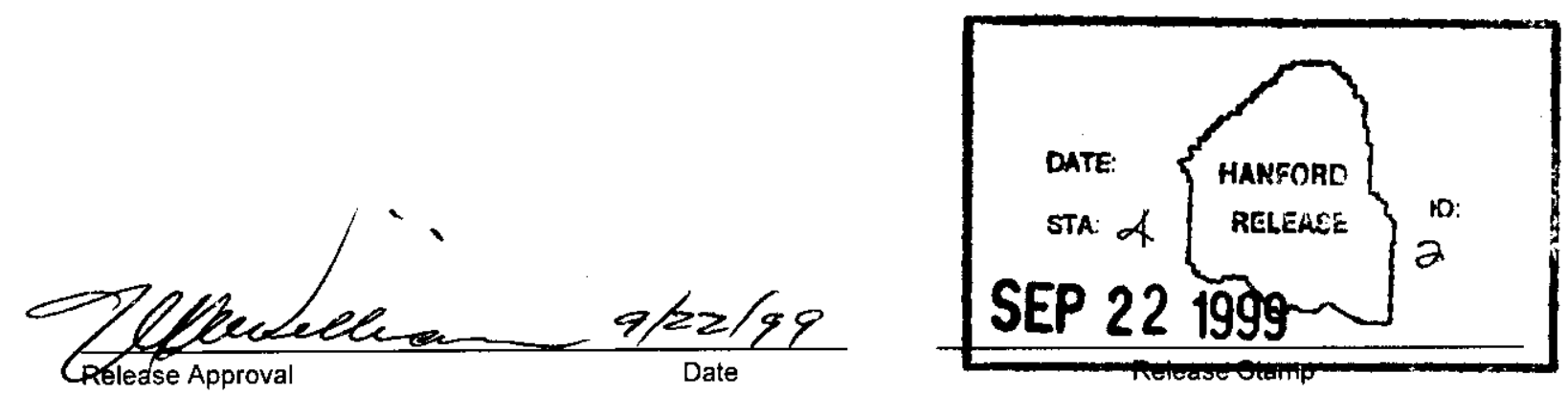


\section{ATP FOR 241-AN FARM K1/K2 CONTINUOUS AIR MONITOR INSTALLATION}

\begin{tabular}{|c|c|c|}
\hline \multicolumn{3}{|c|}{$\begin{array}{l}\text { Last Full Revision: A-0 } \\
\text { Release Date: } 9 / 20 / 99 \\
\text { USQ Screening Number: TF- } 98-1012 \text { Rev. } 8 \\
\text { Approval Designator: Q }\end{array}$} \\
\hline \multicolumn{3}{|c|}{$\begin{array}{l}\text { Current Modification: A-0 } \\
\text { USQ Screening Number: TF-98-1012 Rev. } 8 \\
\text { Approval Designator: Q } \\
\text { PCA Incorporated: N/A }\end{array}$} \\
\hline POSITION/ORG & DELEGATE & DATE \\
\hline Maint. & R. Lee & $\underline{09 / 14 / 99}$ \\
\hline Mgr. & D. Baide & $09 / 20 / 99$ \\
\hline Q.A. & W. Adams & $\underline{09 / 20 / 99}$ \\
\hline & R. D. Freeman & $\underline{09 / 08 / 99}$ \\
\hline Acceptance Review & D. Scott & $\underline{09 / 14 / 99}$ \\
\hline Approval Authority & C.C. Scaief & $\underline{09 / 09 / 99}$ \\
\hline
\end{tabular}




\section{TABLE OF CONTENTS}

1.0 PURPOSE AND SCOPE $\ldots \ldots \ldots \ldots \ldots \ldots$

1.1 PURPOSE .......................... 3

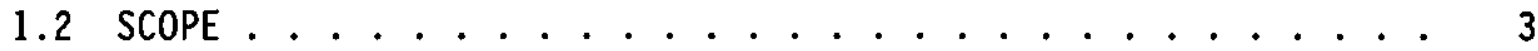

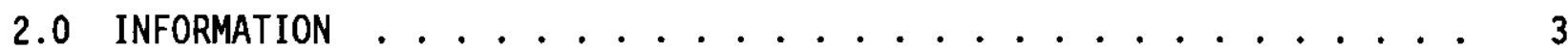

2.1 TERMS AND DEFINITIONS . . . . . . . . . . ..... 3

2.2 RESPONSIBILITIES ................. 3

2.3 REFERENCES .................... 5

2.4 GENERAL INFORMATION ....................... 5

2.4 GENERAL INFORMATION (Cont.) . . . . . . . ..... 6

2.5 RECORDS .................... 6

3.0 PRECAUTIONS AND LIMITATIONS . . . . . . . . . . . . . . . 6

3.1 PERSONNEL SAFETY ................. . . 6

3.2 RADIATION AND CONTAMINATION CONTROL . . . . . . . . . . 7

3.3 ENVIRONMENTAL COMPLIANCE ............... 7

3.4 LIMITS . . . . . . . . . . . . . . . . 7

3.5 CABINET ALARMS ................... 7

4.0 PREREQUISITES . . . . . . . . . . . . . . . . . . . 8

4.1 SPECIAL TOOLS, EQUIPMENT, AND SUPPLIES ......... 8

4.2 CONDITIONS AND ACTIONS .............. 8

5.0 PROCEDURE . . . . . . . . . . . . . . . . . . . . . . 9

5.1 PERFORM K1 FUNCTIONAL TEST . . . . . . . . . . . . . . 9

5.2 PERFORM K2 FUNCTIONAL TEST . . . . . . . . . . 15

5.3 TEST K2 HEATER CONTROLLERS .............. 20

5.4 TEST K2 HEATER CONTROLLERS (Cont.) ........... 21

5.5 ACCEPTANCE CRITERIA . . . . . . . . . . . . 22

TEST EXCEPTION SHEET ..................... 23

TEST LOG . . . . . . . . . . . . . . . . . . 24

ACCEPTANCE TEST PROCEDURE ACCEPTANCE RECORD . . . . . . . . . 25

PROCEDURE PERFORMER SIGNATURE SHEET . . . . . . . . . . . 26

PROCEDURE HISTORY SIGNATURE SHEET . . . . . . . . . . . . . 27

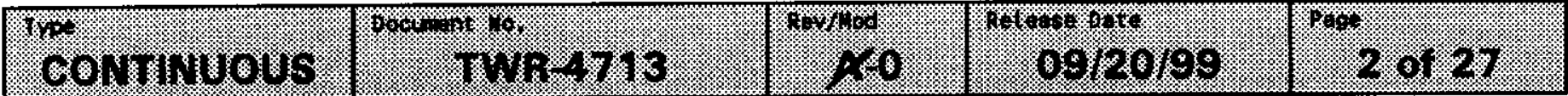




\subsection{PURPOSE AND SCOPE}

\subsection{PURPOSE}

This procedure provides instructions to demonstrate the functional capabilities of the continuous air monitors and the associated al arms in AN-271 and remote al arm at 242-A. As the AMS-3 is removed and the AMS-4 installed, this procedure will ensure the reconnected circuits between the existing and new unit are functioning, before continuing with the funtional test procedure, TF-FT-229-005. The testing will be completed prior to completion of the work document.

\subsection{SCOPE}

The following systems associated with the K1/K2 continuous air monitors will be tested by this Acceptance Test Procedure:

Electrical and Instrument Systems

- Continuous air monitor Flow

- $\quad \mathrm{K} 1 \mathrm{AN}-271$ Alarms

- $\quad$ K1 242-A Remote Alarms

- $\quad$ K2 AN-27l Alarms

- $\quad$ K2 242-A Remote Alarms

- $\quad$ K2 Heater Controllers

- Record Sample Vacuum Pump Interlock

- Heater and Blower Test

\subsection{INFORMATION}

\subsection{TERMS AND DEFINITIONS}
2.1.1 CAM - Continuous Air Monitor
2.1.2 242-A - 242-A Evaporator Bldg.
2.1.3 AN-271 $\underline{\mathrm{AN}-271}$ Instrument $\mathrm{B} 1 \mathrm{dg}$.

\subsection{RESPONSIBILITIES}

2.2.1 Each company or organization participating in this procedure will designate personnel to assume the responsibilities and duties as defined herein for their respective roles.

\begin{tabular}{|c|c|c|c|c|}
\hline Tho & 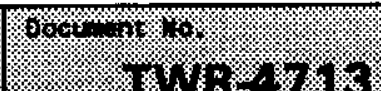 & 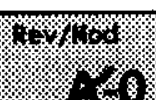 & 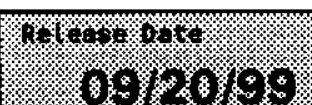 & ris \\
\hline
\end{tabular}




\subsection{RESPONSIBILITIES (Cont.)}

2.2.2 The Design Engineer from Equipment Engineering is responsible for designating and providing a Test Director.

2.2.3 The Cognizant Engineer is responsible for the following:

- Specifying required test sections for each assembly

- Provide technical support to Test Director during testing

- Resolving exceptions to the Acceptance Test

- Preparing and approving procedure changes required to support testing

- Approving acceptance test results

2.2.4 The Test Director is responsible for the following:

- Schedule pre-job, test date and resources required for acceptance testing

- Coordinate test date and testing changes with facility management and all involved parties

- Ensure test is executed in accordance with this procedure

- Ensure accuracy of recorded data, discrepancies, and exceptions

- Stop any test which may cause damage to the system until the test procedure has been revised

- Obtain revisions to the Acceptance Test Procedure, as necessary, to execute test

- Ensure test revisions are approved for use via the redline method before continuing test (see Section 2.4)

- Execution of the test, recording test data, maintaining record copy of test current, approving test results for each section, obtaining approvals for each section and overall test results 


\subsection{RESPONSIBILITIES (Cont.)}

2.2.5 Quality Assurance is responsible for the following:

- Verifying that the procedure sections were performed correctly by witnessing the procedure steps as they occur. Sign at the end of each designated section and the TEST EXCEPTION SHEET.

- Post-test review of test documentation

\subsection{REFERENCES}
2.3 .1
AMS-4 Vendor Information File
2.3.2 IP-0842, RPP Administration
- Vol. I, Section 2.11, "Technical Procedure Control and Use"
- Vol. II, Section 4.9.1, "Lock and Tag Program"
2.3.3 All reference drawings are noted on ECN 646983.

\subsection{GENERAL INFORMATION}

2.4.1 This procedure is prepared to be used individually for each K1 and K2 AMS-4 installation. The two systems share common terminal boxes and have interlocks to the $\mathrm{K} 1$ and $\mathrm{K} 2$ exhausters and remote alarms.

2.4.2 Acceptance Criteria steps are noted by the word VERIFY and require a Test Director signature to ensure the step has been completed. Changes to this procedure that do not change Acceptance Criteria results can be made using the red-line method with the approval of the Test Director, Cognizant Engineer and Quality Assurance. Changes to Acceptance Criteria such as labeling and reference names on alarms and indicators can be made using this method. Changes to the Acceptance Criteria that result in a functional change will require an ECN. All changes will be incorporated in the test report.

2.4.3 Any non-conformance of the instrumentation or unexpected results during testing shall be logged in the TEST EXCEPTION SHEET, and thoroughly documented in the procedure at the affected step.

\begin{tabular}{|c|c|c|c|c|}
\hline OOW & form: & 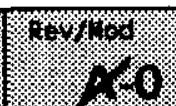 & 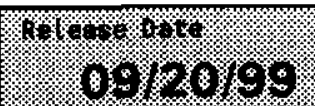 & ? \\
\hline
\end{tabular}




\subsection{GENERAL INFORMATION (Cont.)}

2.4.4 The acceptance test steps detailed in Section 5.0 shall be performed sequentially. The major subsections may be performed out of sequence per the direction of the Test Director if the intent of the test is not compromised. Any step that requires verification of data must also be recorded on the "Working Copy" of this procedure.

2.4.5 Individual test sections will be performed as required to facilitate each AMS-4 installation.

2.4.6 Quality Assurance shall ensure that the test is performed according to procedure. Quality Assurance shall sign and date at the end of each section verifying the procedure steps have been performed correctly.

\subsection{RECORDS}

The completed "Working Copy" of this procedure, Test Exception Sheets, and Test Logs generated by the performance of this procedure will be kept as permanent records through the document release system in the Test Report, TWR-4714.

\subsection{PRECAUTIONS AND LIMITATIONS}

\subsection{PERSONNEL SAFETY}

3.1.1 A daily pretest safety briefing will be held with all test participants and documented in the Test Log.

3.1.2 The primary safety concerns for the performance of this procedure are related to electrical hazards. Any hazard identified during the performance of the procedure shall be reported to the Test Director.

3.1.3 Any other hazards, along with identified personal protective equipment wi11 be addressed in the Job Hazard Analysis and reviewed during the pre-job safety meeting.

\subsection{RADIATION AND CONTAMINATION CONTROL}

3.2.1 When this procedure is performed in a radiological area (except for buffer and underground areas) and the area is not a High Contamination, High Radiation, or Airborne Radioactivity Area, then this is low risk radiological work, and a general Radiation Work Permit must be assigned by Radiological Control Engineering and Technical Support. 


\subsection{RADIATION AND CONTAMINATION CONTROL (Cont.)}

3.2.2 When this procedure is performed in a High Contamination, High Radiation, Airborne Radioactivity Area or if a breach is made to a system or component containing radioactive material then an approved Job Control System package and a job specific Radiation Work Permit is required.

\subsection{ENVIRONMENTAL COMPLIANCE}

None

\subsection{LIMITS}

Performance of test activities shall always include safety and health aspects as delineated in the vendor manuals and as directed by the Test Director.

\subsection{CABINET ALARMS}

The high/low temperature light (DS8) and the white external strobe light will be illuminated/flashing whenever the cabinet temperature is high or low enough to turn on the fan or heater. This can occur on a very hot or cold day. Should this happen, these alarms will not clear. Note the alarm condition on the test exception sheet. Steps that require clearing of all alarms can be checked even though the cabinet alarm is not clear.

\begin{tabular}{|c|c|c|c|c|}
\hline aOHWIIB & 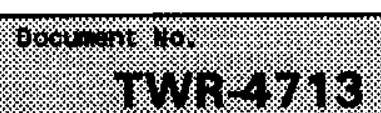 & 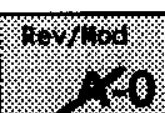 & 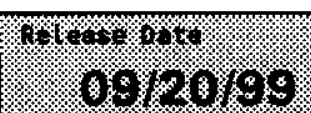 & m. \\
\hline
\end{tabular}




\subsection{PREREQUISITES}

\subsection{SPECIAL TOOLS, EQUIPMENT, AND SUPPLIES}

4.1.1 The following supplies may be needed to perform this procedure and will be made available prior to steps where they are used:

NOTES - The organization accomplishing the test will supply all equipment necessary, unless otherwise noted. The following list is provided as an aid and is not intended to be an all-exhaustive list. Record pertinent information such as model number, serial number and calibration information as required below and in the Test Log.

- If item will not be used, N/A that piece of equipment.

- Assorted hand tools

- Sealed Beta check source for AMS-4, minimum 10,000dpm

- Clamp-on Ammeter, 0-20 AC Amp minimum range, 10\% accuracy or better

- Heat gun and circuit cooler

\subsection{CONDITIONS AND ACTIONS}

The following conditions must be met before this procedure may commence:

4.2.1 A pre-job safety meeting has been held before performing this procedure in accordance with IP-0842, Vol V, Section 4.1, PRE-JOB SAFETY MEETING FORM.

4.2.2 Test Director VERIFY Section 4.0 has been completed by signing below.

Signature

Printed Name

Date

Test Director 


\subsection{PROCEDURE}

\subsection{PERFORM K1 FUNCTIONAL TEST}

\section{PRETEST SETUP}

5.1.1 OBTAIN permission from SOM to perform test.

5.1.2 ENSURE procedure 6-TF-077 has been completed on the KI cabinet.

5.1.3 ENSURE vacuum pumps are plugged into the appropriate receptacle, - Monitoring pump "unswitched" and record sample pump "switched".

5.1.4 ENSURE continuous air monitor is plugged into AC power.

5.1.5 APPLY power to the continuous air monitor, AND PROCEED when the READY light turns on.

5.1.6 ENSURE Kl exhauster is not running.

5.1.7 ENSURE KI CAM installation data sheet (ET-07245) from procedure 6-RM-168 has been completed.

5.1.8 ENSURE filter is installed in AMS-4.

5.1.9 CHECK Pretest setup is complete.

\section{IEST}

5.1.10 ENSURE power is on to monitoring cabinet.

5.1.11 VERIFY record sample pump is off and monitor vacuum pump is running.

\section{Signature
Test Director}

$\overline{\text { Printed Name }} \overline{\text { Date }}$

5.1.12 VERIFY that "Stack Operating Light" on the cabinet Connection Box is not 1it.

Signature
Test Director

5.1.13 APPLY temporary power from an unswitched outlet to the record sample vacuum pump, AND ENSURE the record sample pump is running. 


\subsection{PERFORM K1 FUNCTIONAL TEST (Cont.)}

5.1.14 VERIFY that the record sample flow can be adjusted, using the regulator, to $120(+/-12)$ SCFH as indicated on the rotameter.

RECORD the flow value. SCFH

Signature Drinted Name Date

Test Director

5.1.15 VERIFY the monitor flow is set to $2.0(+/-0.2)$ CFM as indicated on the continuous air monitor display. Adjust as required using the regulator.

RECORD the flow value.

\section{Signature Drinted Name Date \\ Test Director}

5.1.16 IF the appropriate flow range CANNOT be achieved, STOP the test AND CONTACT Engineering before continuing.

RECORD SAMPLE PUMP LOW FLOW ALARM

5.1.17 ENSURE that the AN K1 Record Sample Pump fail alarm (Faceplate 68/Block 3) at the 242-A Evaporator Monitor and Control System is clear.

5.1.18 DISCONNECT power to the record sample vacuum pump.

5.1.19 VERIFY that "Low Record Flow" light at the Local Alarm Box is lit.

\section{Signature \\ Test Director}

5.1.20 VERIFY that AN K1 Record Sample Pump fail alarm (Faceplate 68/Block 3) at the 242-A Evaporator Monitor and Control System is activiated.

$\begin{array}{ll}\text { Signature } & \text { Printed Name } \\ \text { Test Director } & \text { Date }\end{array}$

5.1.21 RESTORE power to the record sample vacuum pump.

5.1.22 RESET local alarm box, AND ACKNOWLEDGE remote alarms.

5.1.23 CHECK that alarms and lights have cleared.

\%




\subsection{PERFORM K1 FUNCTIONAL TEST (Cont.)}

MONITOR SAMPLE PUMP LOW FLOW ALARM

5.1.24 ENSURE that the AN Kl monitor sample pump fail alarm (Faceplate 68/Block 2) at the 242-A Evaporator Monitor and Control System is clear.

5.1.25 ENSURE that the AN Farm Tank Exh Rad Mon Fail (Faceplate $68 /$ B 1 ock 1) is clear.

5.1.26 ENSURE that AN-271 ANN 103, Window 9 Primary Exh Stack CAM Failure is clear.

5.1.27 REMOVE power to the monitor sample vacuum pump.

5.1.28 VERIFY that "Low Beta Flow" light at the Local Alarm Box is lit.

Signature
Test Director

5.1.29 VERIFY that continuous air monitor malfunction light is lit with an indication of Low Flow (Response time may be delayed).

\section{Signature
Test Director}

5.1.30 VERIFY all alarms noted in step 5.1.24, 5.1.25 and 5.1.26 are activated.
Printed Name Date 


\subsection{PERFORM K1 FUNCTIONAL TEST (Cont.)}

HIGH RADIATION ALARMS

5.1.34 ENSURE the CAM HI Rad Alarm on Annunciator 102 at AN-271 and the 242-A Evaporator Monitor and Control System (Faceplate 68, Block 0) are clear.

5.1.35 ADJUST the continuous air monitor to a fixed flow value of 2 CFM and the beta alarm setpoint to $500 \mathrm{cpm}$.

5.1.36 REMOVE power from the monitor sample vacuum pump. (Low Beta Flow light on the local alarm box and the Evaporator flow alarm will actuate.)

5.1.37 REMOVE the filter AND PLACE a minimum 10,000 dpm beta check source into the continuous air monitor chamber and allow the HI Radiation alarm to actuate.

5.1.38 VERIFY that CAM HI Rad alarm on Annunciator 102 Window 10 at $\mathrm{AN}-271$ and the 242-A Evaporator Monitor and Control System (Faceplate 68/Block 0 ) are activiated.

$\overline{\text { Signature }} \overline{\text { Printed Name }}$

5.1.39 VERIFY that HI Beta Rad light on the local alarm box is lit.

Signature
Test Director

5.1.40 REMOVE the beta check source AND REPLACE the filter.

5.1.41 RESTORE power to the monitor sample vacuum pump.

5.1.42 RETURN continuous air monitor fixed flow value to normal setting.

5.1.43 RETURN continuous air monitor beta setpoint to $3000 \mathrm{cpm}$.

5.1.44 RESET local alarm box AND ACKNOWLEDGE remote and alarms.

5.1.45 CHECK that a 7 arms and lights have cleared. 


\title{
5.1 PERFORM K1 FUNCTIONAL TEST (Cont.)
}

\author{
HEATER AND BLOWER TEST
}

NOTE - THE CABINET BLOWER THERMOSTAT (LEFT SIDE OF THERMOSTAT

BOX) ACTIVATES AT $95+/-5$ DEGREES $F$ AND DEACTIVATES AT 85

$+/-5$ DEGREES $F$. THE HEATER THERMOSTAT (RIGHT SIDE OF THERMOSTAT BOX) ACTIVATES AT $65+/-5$ DEGREES $F$ AND

DEACTIVATES AT $75+/-5$ DEGREES $F$.

5.1.46 APPLY heat or cold as required to cabinet blower thermostat and VERIFY cabinet blower turns on and off.

Signature
Test Director

5.1.47 APPLY heat or cold as required to heater thermostat and VERIFY heater turns on and off.

Signature
Test Director

\section{EXHAUSTER RECORD SAMPLE PUMP INTERLOCK}

5.1.48 ENSURE record sample vacuum pump is plugged into a switched outlet.

5.1.49 ENSURE record sample vacuum pump is not running.

5.1.50 OBTAIN permission from SOM to start exhauster.

NOTE - TEST DIRECTOR TO NOTIFY SOM THAT THE CAM INTERLOCK SYSTEM WILL NOT BE DECLARED OPERATIONAL UNTIL THE FUNCTIONAL TEST HAS BEEN PERFORMED. REFER TO THE WORK PACKAGE FOR THE MONITORING REQUIREMENTS DURING THIS PERIOD.

5.1.51 START K1 exhauster AND VERIFY that record sample vacuum pump starts.

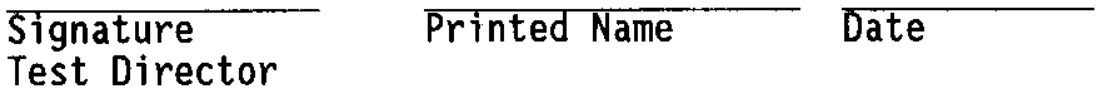

5.1.52 RESET the local alarm box AND VERFIY that "Stack Operating" light at the cabinet connection box is $1 \mathrm{it}$.

$\begin{array}{lll}\text { Signature } & \text { Printed Name } & \text { Date } \\ \text { Test Director } & \end{array}$

5.1.53 CHECK that all local and remote alarms have cleared.

\begin{tabular}{|c|c|c|c|c|}
\hline tiso & $60 \mathrm{cos} ; x)$ & 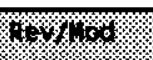 & 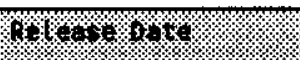 & \% \\
\hline 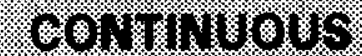 & (1) অ. & 1. & ন & 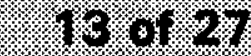 \\
\hline
\end{tabular}




\subsection{PERFORM K1 FUNCTIONAL TEST (Cont.)}

5.1.54 Test Director VERIFY all steps in Section $\mathbf{5 . 1}$ have been completed by signing below.

Signature Drinted Name Date

Test Director

Quality Assurance VERIFY that Section 5.1 has been completed by signing below.

Signature
Quality Control

\begin{tabular}{|c|c|c|c|c|}
\hline & 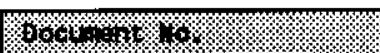 & 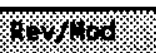 & 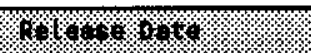 & 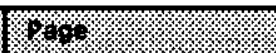 \\
\hline 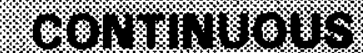 & $196-1716$ & 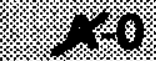 & o5/2015: & 14 or 27 \\
\hline
\end{tabular}




\subsection{PERFORM K2 FUNCTIONAL TEST}

\section{PRETEST SETUP}

5.2.1 OBTAIN permission from SOM to perform test.

5.2.2 ENSURE procedure 6-TF-077 has been completed on the K2 cabinet.

5.2.3 ENSURE vacuum pumps are plugged into the appropriate receptacle, - Monitoring pump "unswitched" and record sample pump "switched".

5.2.4 ENSURE continuous air monitor is plugged into AC power.

5.2.5 APPLY power to the continuous air monitor, AND PROCEED when the READY light turns on.

5.2.6 ENSURE K2 exhauster is not running.

5.2.7 ENSURE K2 CAM installation data sheet (ET-07244) from procedure 6-RM-168 has been completed.

5.2.8 ENSURE filter is installed in AMS-4.

5.2.9 CHECK Pretest setup is complete.

\section{TEST}

5.2.10 SWITCH power on to monitoring cabinet.

5.2.11 VERIFY record sample pump is off and monitor vacuum pump is running.

Signature
Test Director Date

5.2.12 VERIFY that "Stack Operating Light" on the cabinet Connection Box is not lit.

$\begin{array}{lll}\text { Signature } & \text { Printed Name } & \text { Date } \\ \text { Test Director } & \end{array}$

5.2.13 APPLY temporary power from an unswitched outlet to the record sample vacuum pump, AND ENSURE that record sample pump is running. 


\subsection{PERFORM K2 FUNCTIONAL TEST (Cont.)}

5.2.14 VERIFY that the record sample flow can be adjusted, using the regulator, to $120(+/-12)$ SCFH as indicated on the rotameter.

RECORD the flow value. SCFH

Signature Printed Name Date

5.2.15 VERIFY the monitor flow is set to $2.0(+/-0.2)$ CFM as indicated on the continuous air monitor display. Adjust as required using the regulator.

RECORD the flow value.

Signature
Test Director

5.2.16 IF the appropriate flow range CANNOT be achieved, STOP the test AND CONTACT Engineering before continuing.

RECORD SAMPLE PUMP LOW FLOW ALARM

5.2.17 ENSURE that the AN K2 Record Sample Pump fail alarm (Faceplate 68/Block 7) at the 242-A Evaporator Monitor and Control System is clear.

5.2.18 DISCONNECT power to the record sample vacuum pump.

5.2.19 VERIFY that "Low Record Flow" light at the Local Alarm Box is lit.

Signature
Test Director

5.2.20 VERIFY that AN K2 Record Sample Pump fail alarm at the 242-A Evaporator Monitor and Control System (Faceplate $68 /$ Block 7 ) is activiated.

Signature
Test Director

5.2.21 RESTORE power to the record sample vacuum pump.

5.2.22 RESET local alarm box, AND ACKNOWLEDGE remote alarms.

5.2.23 CHECK alarms and lights have cleared.

\begin{tabular}{|c|c|c|c|c|}
\hline 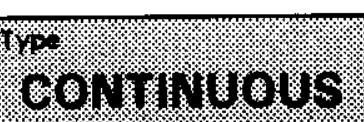 & 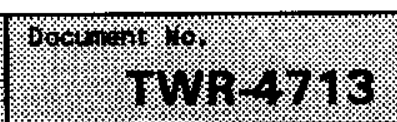 & 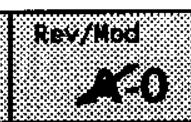 & 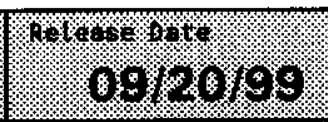 & 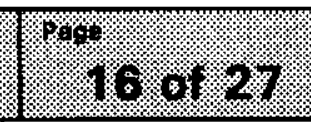 \\
\hline
\end{tabular}




\subsection{PERFORM K2 FUNCTIONAL TEST (Cont.)}

MONITOR SAMPLE PUMP LOW FLOW ALARM

5.2.24 ENSURE that the AN K1 monitor sample pump fail alarm (Faceplate 68/Block 6) at the 242-A Evaporator Monitor and Control System is clear.

5.2.25 ENSURE that the AN Farm Tank Exh Rad Mon Fail (Faceplate $68 /$ B 1ock 5) is clear.

5.2.26 ENSURE that AN-271 ANN 103, Window 8 Annulus Exh Stack CAM Failure is clear.

5.2.27 REMOVE power to the monitor sample vacuum pump.

5.2.28 VERIFY that "Low Beta Flow" light at the Local Alarm Box is lit.

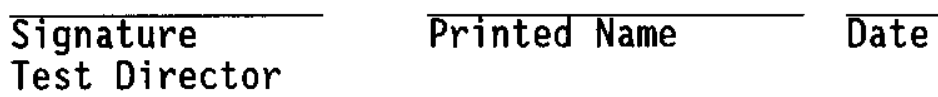

5.2.29 VERIFY that continuous air monitor malfunction light is lit with an indication of Low Flow (Repsonse time may be del ayed).

Signature Drinted Name Date

5.2.30 VERIFY all alarms noted in step 5.2.24, 5.2.25 and 5.2.26 are activated.

Signature
Test Director

5.2.31 RESTORE power to the monitor sample vacuum pump.

5.2.32 RESET local alarm box, ACKNOWLEDGE any CAM alarms, AND ACKNOWLEDGE remote alarms.

5.2.33 CHECK that alarms and lights have cleared AND the CAM ready light is $0 N$.

\section{HIGH RADIATION ALARMS}

5.2.34 ENSURE the CAM HI Rad Alarm on Annunciator 102 Window 9 at AN-271 and the 242-A Evaporator Monitor and Control System (Faceplate 68/Block 4) are clear. 


\subsection{PERFORM K2 FUNCTIONAL TEST (Cont.)}

5.2.35 ADJUST the continuous air monitor to a fixed flow value of 2 CFM and the beta alarm setpoint to $500 \mathrm{cpm}$.

5.2.36 REMOVE power from the monitor sample vacuum pump. (Low Beta Flow light on the local alarm box and Evaporator flow alarm will actuate.)

5.2.37 REMOVE the filter AND PLACE a minimum 10,000 dpm beta check source into the continuous air monitor chamber and allow the HI Radiation alarm to actuate.

5.2.38 VERIFY that CAM HI Rad alarm on Annunciator 102 Window 9 at $\mathrm{AN}-271$ and the 242-A Evaporator Monitor and Control System (Faceplate $68 /$ B 1ock 8 ) are activiated.

Signature
Test Director

5.2.39 VERIFY that HI Beta Rad light on the local alarm box is lit.

Signature
Test Director $\quad \overline{\text { Printed Name }} \quad \overline{\text { Date }}$

5.2.40 REMOVE the beta check source AND REPLACE the filter.

5.2.41 RESTORE power to the monitor sample vacuum pump.

5.2.42 RETURN continuous air monitor fixed flow value to normal setting.

5.2.43 RETURN continuous air monitor beta setpoint to $3000 \mathrm{cpm}$.

5.2.44 RESET local alarm box, AND ACKNOWLEDGE remote alarms.

5.2.45 CHECK that alarms and lights have cleared.

\section{HEATER AND BLOWER TEST}

NOTE - THE CABINET BLOWER THERMOSTAT (LEFT SIDE OF THERMOSTAT BOX) ACTIVATES AT $95+/-5$ DEGREES $F$ AND DEACTIVATES AT 85 $+/-5$ DEGREES $F$. THE HEATER THERMOSTAT (RIGHT SIDE OF THERMOSTAT BOX) ACTIVATES AT $65+/-5$ DEGREES $F$ AND DEACTIVATES AT $75+/-5$ DEGREES $F$. 


\subsection{PERFORM K2 FUNCTIONAL TEST (Cont.)}

5.2.46 APPLY heat or cold as required to cabinet blower thermostat and VERIFY cabinet blower turns on and off.

Signature Printed Name Date

5.2.47 APPLY heat or cold as required to heater thermostat and VERIFY heater turns on and off.

Signature
Test Director

\section{EXHAUSTER RECORD SAMPLE PUMP INTERLOCK}

5.2.48 ENSURE record sample vacuum pump is plugged into switched outlet.

5.2.49 ENSURE record sample vacuum pump is not running.

5.2.50 OBTAIN permission from SOM to start exhauster.

NOTE - TEST DIRECTOR TO NOTIFY SOM THAT THE CAM INTERLOCK SYSTEM WILL NOT BE DECLARED OPERATIONAL UNTIL THE FUNCTIONAL TEST HAS BEEN PERFORMED. REFER TO THE WORK PACKAGE FOR THE MONITORING REQUIREMENTS DURING THIS PERIOD.

5.2.51 START K2 exhauster and VERIFY that record sample vacuum pump starts.

Signature
Test Director

5.2.52 RESET the local alarm box AND VERIFY that "Stack Operating" light at the cabinet connection box is 1 it.

Signature
Test Director

5.2.53 CHECK that all local and remote alarms have cleared.

5.2.54 Test Director VERIFY all steps in Section 5.2 have been completed by signing below.

Signature
Test Director

\begin{tabular}{|c|c|c|c|c|}
\hline arom & 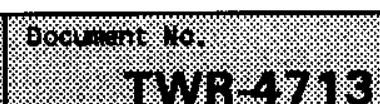 & 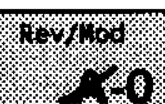 & Rinements: & 4is: \\
\hline
\end{tabular}




\subsection{TEST K2 HEATER CONTROLLERS}

Quality Assurance VERIFY that Section 5.2 has been completed by signing below.

Signature Printed Name Date

Quality Control

NOTES - The purpose of this test section is to check K2 heater controllers.

- In the A Exhaust Train the upper heater elements should be on whenever the fan is running. The lower heater elements are controlled by Differential Controller AN241-VTA-TDC709. In the B Exhaust Train, the controller is not functioning and is jumpered out. Both the upper and lower elements are powered whenever the B train fan is running.

\section{A EXHAUST TRAIN RUNNING}

5.3.1 To test A Exhaust train, use a clamp-on ammeter and VERIFY that the Upper and Lower heating elements in the B Exhaust train are NOT powered.

Signature
Test Director

5.3.2 VERIFY that Upper heating elements in the A Exhaust train are powered.

\section{Signature \\ Test Director}

5.3.3 Using the clamp-on ammeter, MEASURE the current in one phase of the Lower heater in the A Exhaust train.

5.3.4 VERIFY that Differential Heater Controller setpoint can be changed to turn power on and off at the lower heater.

Signature
Test Director

\section{$\overline{\text { Printed Name Date }}$}




\subsection{TEST K2 HEATER CONTROLLERS (Cont.)}

\section{B EXHAUST TRAIN RUNNING}

5.4.1 To test B Exhaust train, use a clamp-on ammeter and VERIFY that the Upper and Lower heating elements in the $A$ Exhaust train are NOT powered.

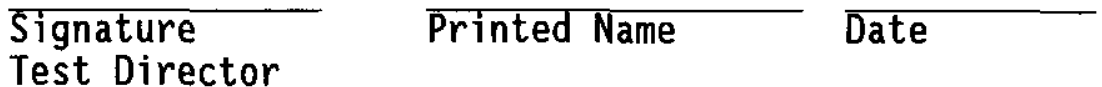

5.4.2 VERIFY that the Upper and Lower heating elements in the $B$ Exhaust train are powered.

Signature
Test Director

5.4.3 Test Director VERIFY all steps in Section 5.3, 5.4 have been completed by signing below.

Signature
Test Director
Quality Assurance VERIFY that Section $5.3,5.4$ has been
completed by signing below.

Signature
Quality Control




\subsection{ACCEPTANCE CRITERIA}

5.5.1 VERIFY that all acceptance criteria steps have been completed satisfactorly and exceptions resolved.

\begin{tabular}{lll}
$\begin{array}{l}\text { Signature } \\
\text { Test Director }\end{array}$ & Printed Name & \\
\hline $\begin{array}{l}\text { Signature } \\
\text { Cognizant Engineer }\end{array}$ & Printed Name & \\
\hline $\begin{array}{l}\text { Signature } \\
\text { Quality Control }\end{array}$ & Printed Name & Date
\end{tabular}

5.5.2 COMPLETE Acceptance Test Procedure Acceptance Record. 


\section{TEST EXCEPTION SHEET}

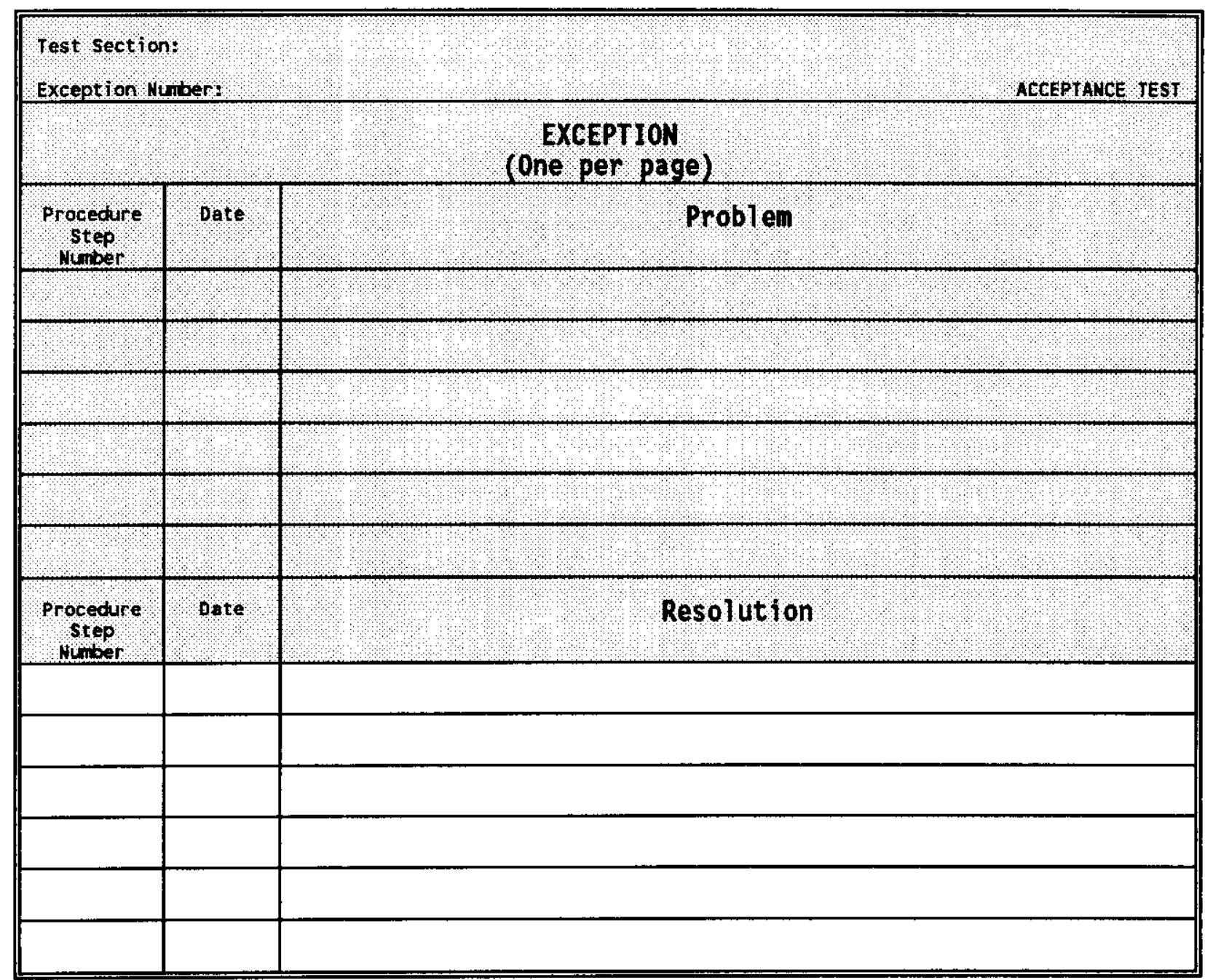

\section{EXCEPTION RESOLUTION COMPLETE}

\begin{tabular}{|c|c|c|}
\hline $\begin{array}{l}\text { Signature } \\
\text { Test Director }\end{array}$ & Printed Name & Date \\
\hline $\begin{array}{l}\text { Signature } \\
\text { Cognizant Engineer }\end{array}$ & Printed Name & Date \\
\hline $\begin{array}{l}\text { Signature } \\
\text { Qual ity Assurance }\end{array}$ & Printed Nane & Date \\
\hline
\end{tabular}


TEST LOG

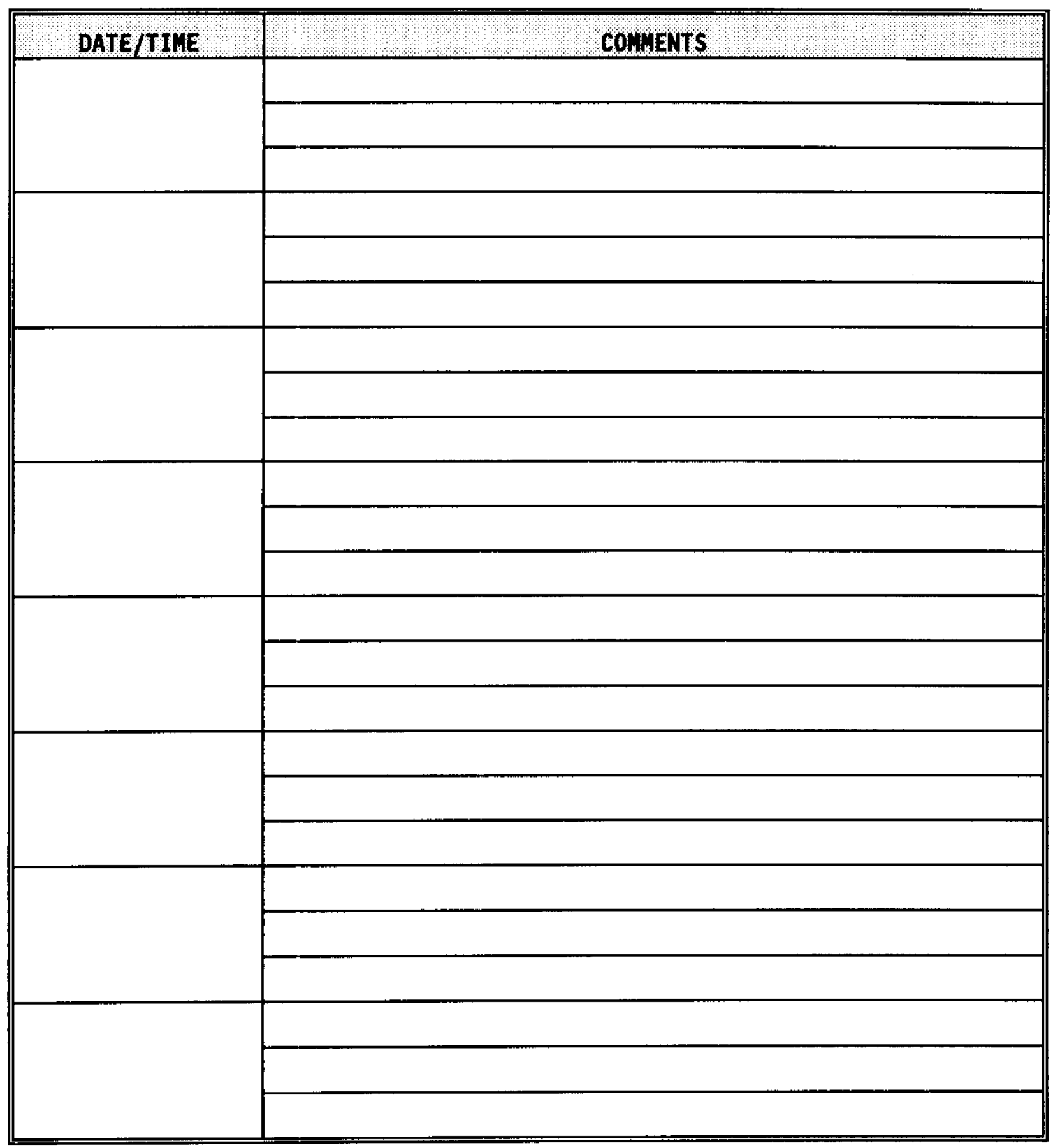




\section{ACCEPTANCE TEST PROCEDURE ACCEPTANCE RECORD}

This Acceptance Test Procedure has been completed and the test results, including redline changes, exceptions, and exception resolutions, have been reviewed for compliance with the intent of the Purpose (Section 1.0). The test results are accepted by the undersigned:

Cognizant Engineer (Signature) (Print Name) Date

Cognizant Manager (Signature) (Print Name) Date

Tank Farms Operations (Signature) (Print Name) Date

Quality Assurance (Signature) $\quad$ (Print Name) Date

Test Director (Signature) (Print Name) Date




\section{PROCEDURE PERFORMER SIGNATURE SHEET}

All personnel who will be performing, initialing and signing the procedure shall enter their printed name, signature and initials below. NAME (PRINT) 


\section{PROCEDURE HISTORY SIGNATURE SHEET}

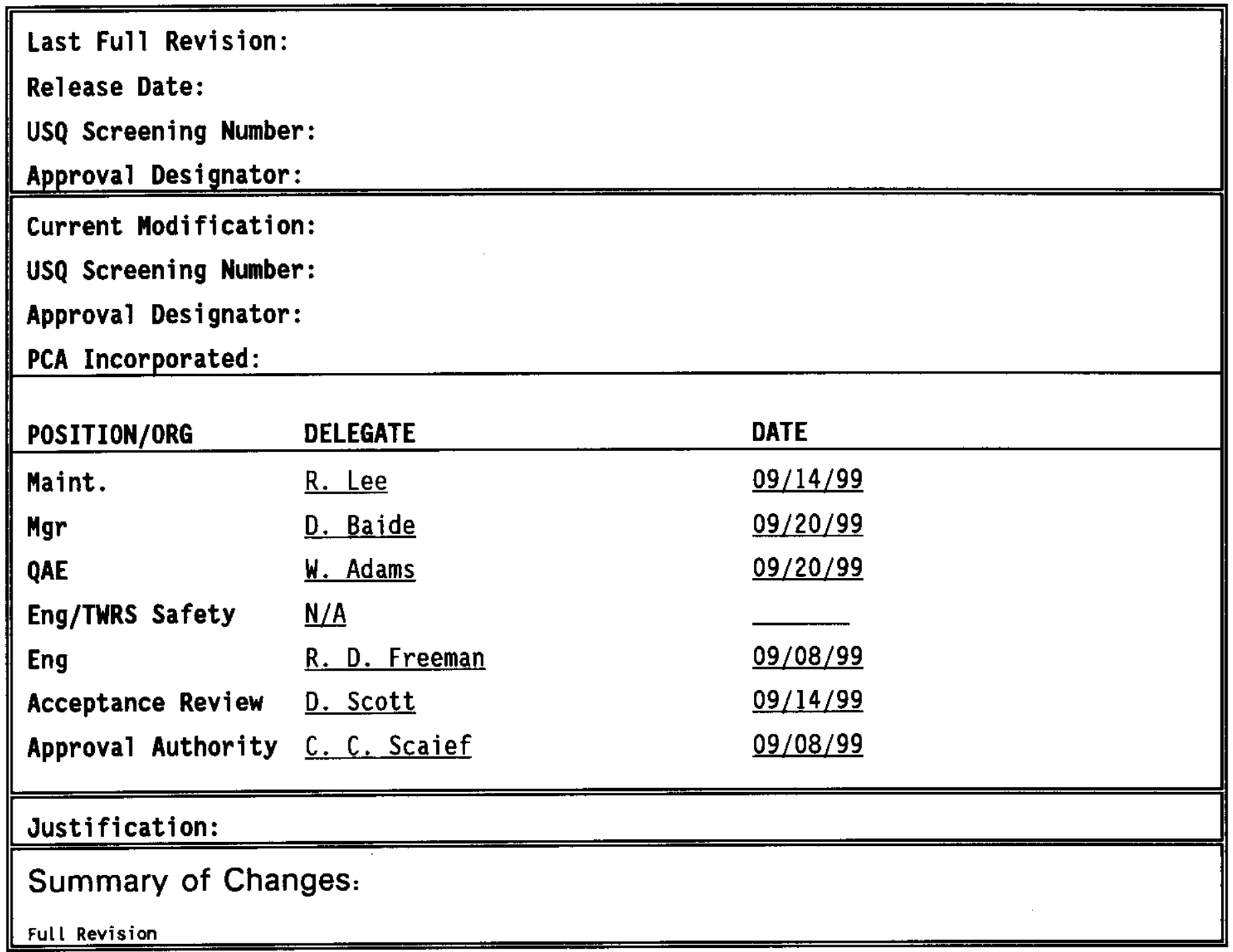




\section{DISTRIBUTION SHEET}

To

Distribution

Project Title/Work Order

Acceptance Test Procedure for 241-AN Farm K1/K2 Continuous Air

Monitor Installation, TWR-4713

LMHC Correspondence Control

D. G. Baide

W. E. Bryan

K. E. Carpenter

J. W. Comer

R. D. Freeman

R. G. Lee

W. J. Lehman

R. S. Nicholson

S. H. Rifaey

C. C. Scaief

D. $\operatorname{scot} t$

TSRC
From

R. D. Ereeman
Page 1 of 1
Date $09 / 09 / 99$
EDT No. 619708
ECN No. N/A

Text

MSIN

H7-09

S5-05

S5-05

$\mathrm{R} 2-47$

R2 -82

S5-05

S5-06

R2-82

S5-05

RI-56

$\mathrm{R} 1-56$

S5-07

R1-10 \begin{tabular}{c|c|c|c|}
\hline Text & & Attach./ & EDT/ECN \\
With All & Text Only & Appendix & OnTy \\
\hline
\end{tabular} Attach.

$\mathrm{X}$ Only 